\title{
THE LENDING CHANNELS OF MONETARY POLICY TRANSMISSION MECHANISMS: THE CASE OF JORDAN
}

\author{
DOI: 10.17261/Pressacademia.2021.1471 \\ JEFA- V.8-ISS.4-2021(2)-p.167-173
}

Muhanned Obeidat ${ }^{1}$, Ahmad Tarawneh ${ }^{2}$, Mohammad Khataibeh ${ }^{3}$, Ghassan Omet $^{4}$

${ }^{1}$ University of Jordan, Department of Finance, Amman, Jordan. mu.obeidat@ju.edu.jo, ORCID: 0000-0002-8988-1291

${ }^{2}$ University of Jordan, Department of Finance, Amman, Jordan. ah.altarawneh@ju.edu.jo, ORCID: 0000-0002-5833-1887

${ }^{3}$ University of Jordan, Department of Finance, Amman, Jordan. khataybeh@ju.edu.jo, ORCID: 0000-0003-3599-903X

${ }^{4}$ University of Jordan, Department of Finance, Amman, Jordan. gomet@ju.edu.jo, ORCID: 0000-0002-8988-1387

\begin{tabular}{l}
\hline Date Received: September 10, $2021 \quad$ Date Accepted: November 29, $2021 \quad$ open OACCEss \\
\hline To cite this document BY \\
Obeidat, M., Tarawneh, A., Khataibeh, M., Omet, G., (2021). The lending channels of monetary policy transmission mechanisms: the case of \\
Jordan. Journal of Economics, Finance and Accounting (JEFA), 8(4), 167-173. \\
Permanent link to this document: http://doi.org/10.17261/Pressacademia.2021.1471 \\
Copyright: Published by PressAcademia and limited licensed re-use rights only. \\
\hline
\end{tabular}

\section{ABSTRACT}

Purpose- Economists have given special attention to understanding the transmission mechanisms through which monetary policy affects the real economy. Indeed, understanding these mechanisms has resulted in the publication of numerous theoretical and empirical papers. This paper examines the effectiveness of the lending channel of monetary policy in Jordan.

Methodology- To investigate the monetary policy transmission mechanism in Jordan through its lending channel, this paper uses the time period 1992-2019 and time series techniques including stationarity test, lag length selection criteria, co-integration, Vector Error Correction Model (VECM), and some stability tests.

Findings- The results show that monetary policy is not effective in its lending channel. Changes in interest rates do not cause a reciprocal and opposite changes in total bank credit to the private sector. However, the results also reveal that that there is a stable (negative) long run relationship between bank credit to individuals and to the construction sector and monetary policy. These findings, however, are somewhat encouraging given the fact that credit to individuals and to the construction sector account for about 55 percent of total credit to the private sector.

Conclusion- To increase the effectiveness of the transmission mechanism of monetary policy in Jordan, relevant stakeholders would be welladvised to consider the establishment of a government (and corporate) securities market. Indeed, the absence if such a market weakens the transmission of changes in the short term policy rate to other points on the yield curve.

Keywords: Jordan, bank credit, monetary policy transmission mechanism, lending channel.

JEL Codes: E50, E51, E52

\section{INTRODUCTION}

The subject matter of the transmission of monetary policy remains one major source of research in economics. However, while economists, on average, agree that in the short run, monetary policy can have an impact on the real economy, its transmission mechanism still remains a "black box" (Bernanke and Gertler, 1995).

The transmission mechanism of monetary works through various channels. For example, a contractionary monetary policy decreases the money supply, and as a result, increases the nominal and real interest rates. The negative impact of the rise in interest rates on consumption and investment puts downward pressure on output and prices.

Within the context of the monetary policy transmission mechanism, it is useful to note that in Jordan, the local currency (Dinar) is pegged to the U.S. dollar. Naturally, and to maintain this policy, the Central Bank of Jordan (CBJ) maintains a policy of interest rate differential with the United States, and continues to act, if and when needed, to ensure that reserve targets are always maintained.

The emergence of COVID-19 (in late January 2020) has forced many central banks across the globe to adopt expansionary monetary policies. For example, since March 2020, the CBJ has cut its key policy rates two times (225 points in total). In addition, the $\mathrm{CBJ}$ reduced the minimum reserve ratio on bank deposits from 7 percent to 5 percent. This reduction, according 
to the CBJ, is expected to provide the economy with around JD 550 million or US\$780 million additional liquidity. In addition, the $\mathrm{CBJ}$ allowed banks to postpone loan repayments by clients in the impacted sectors.

While the economic implications of CIVID-19 on the Jordanian economy still evolve, already the signs are clear. For example, the overall unemployment rate has suddenly increased from 19.0 percent ( $4^{\text {th }}$ quarter of 2019) to 24.7 percent $\left(4^{\text {th }}\right.$ quarter of 2020). This implication (and others), makes one can argue that the role of fiscal and monetary policies could not have been more important.

Within the context of monetary policy in Jordan, and the implications of COVID-19, understanding the monetary policy transmission mechanism has become even more important than ever in the design and implementation of monetary policy. Indeed, what is needed in these days is more effective transmission to the real economy.

Relative to the above-mentioned observations and arguments, this paper examines the monetary policy transmission mechanism in Jordan through its lending channel. The paper looks at the nexus between total credit to the private sector and the CB's re-discount rate and real Gross Domestic Product (GDP). In addition, the paper examines the nexus between each of the largest borrowers (construction sector and the retail-end of credit / individuals) and the CBJ's re-discount rate and real GDP.

The organization of the rest of this paper is presented as follows. In section2, a brief review of the relevant literature is presented. In sections 3 and 4, we present the data and methodology and empirically estimated results respectively. Finally, in section 5 , we summarize the main findings of the paper and outline some recommendations whose objective is to enhance the transmission of monetary policy in Jordan.

\section{THE MONETARY POLICY TRANSMISSION MECHANISM: LITERATURE REVIEW}

The monetary policy transmission mechanism is the process through which monetary policy affects the real economy. The transmission mechanism of monetary works through various channels (Mishkin, 1995). These are the interest rate channel, lending channel, asset price channel, exchange rate channel, and the expectations channel.

The interest rate channel: This channel postulates that a contractionary monetary policy decreases the money supply, and as a result, increases nominal and real interest rates. The negative impact of the rise in rates on consumption and investment decreases output and prices.

The lending channel: This channel postulates that a contractionary monetary policy reduces the reserves of banks, and in turn, their supply of loans. As one might expect, the fall in the supply of loans puts downward pressure on both consumption and investment.

The asset price channel. This channel postulates that an expansionary monetary policy appreciates the prices of assets and in turn, through wealth and liquidity effects, increases investment (Tobin's q theory) and consumption.

The exchange rate channel: This channel postulates that a contractionary monetary policy increases interest rates, and in turn, appreciates the local currency. Again, as one might expect, the appreciation of the local currency affects the performance of the local economy in terms of its competitiveness in international trade. In other words, exports might decrease and imports might increase.

The expectations channel: This channel postulates that a contractionary monetary policy signals that the inflation rate in the future will be lower. The expectation of lower inflation, in turn, affects the savings and investments decisions of households and firms respectively.

As mentioned in the introduction, the transmission channels of monetary policy have resulted in the publication of numerous empirical papers. Within this context, it is useful to note that the empirical literature is not conclusive. The effectiveness of any channel varies between economies, and depends on specific features such as the structure of the financial system (Cecchetti, 1999).

On average, the empirical papers that examine the transmission mechanism of monetary policy estimate a vector autoregressive (VAR) model focusing on a reduced-form relationships between a monetary policy measure and a set of variables that include, for example, real output, inflation, credit growth, stock market index, and others.

Some of the early papers using this methodology to examine the various monetary policy transmission mechanisms in advanced economies include Brayton and Mauskopf (1985), Bernanke and Blinder (1992), Sims (1992), Bernanke and Gertler (1995), Cushman and Zha (1995), Kashyap and Stein (1995), Leeper et al (1996), Christiano et al (1998), Monticelli and Tristani (1999), and Peersman and Smets (2001). For example, Peersman and Smets (2001), for example, perform the VAR approach to (1980-1998) to examine the macro-economic impacts of the change in monetary policy in the euro area, on the real effective exchange rate, output, and inflation. Based on the results, it is stated that a temporary rise in nominal and real short-term rates are followed by appreciation of the exchange rate, and a temporary decrease in real GDP. 
Following the classical papers that examine the monetary policy transmission mechanisms in advanced economies, there has been, recently, a growing number of researchers that do the same effort on emerging and developing economies. Again, some of the more recent papers include Barajas et al. (2018), Rasheed (2018), Abbas et al. (2019), Mukhtar and Younas (2019), Nguyen et al (2019), Brandao-Marques (2020), Can et al. (2020), and Mishi and Tsegaye (2020).

As far as Arab economies are concerned, for example, Rasheed (2018) examines the transmission mechanism of monetary policy in Morocco. Using a structural vector auto-regression model (SVAR), the results indicate that monetary policy gets transmitted through both the credit and interest rate channels. Through the exchange rate and asset prices, however, there is no transmission. Within the same spirit, Poddar et al. (2006) examine monetary policy transmission in the Jordanian economy. Based on the quarterly data (first quarter 1996 - first quarter 2005), and the estimated VARs, it is concluded that monetary policy in Jordan has no impact on output. In addition, equity prices and the exchange rate do not transmit monetary policy to economic activity. The monetary policy transmission mechanism has also been examined by Al-Jarrah et al. (2016). Their study examines the lending channel of monetary policy using bank-level data (panel data analysis). The results indicate that bank lending responds positively to changes in monetary policy. In other words, the increase in short-term interest rate increases bank lending. This is why Al-Jarrah et at. (2016) recommend to the Central Bank of Jordan to "watch the concomitant consequences of the monetary policy transmission and monitor the micro-dynamics of individual banks as the excessive expansion in loan supply may exposes the banks to higher levels of operating risks and other forms of risk" (AlJarrah et al., 2016).

\section{THE DATA AND METHODOLOGY}

To examine the lending channel of monetary policy in Jordan, the following three models are estimated:

$\ln \left(\right.$ Credit Private $\left.e_{t}\right)=\lambda+\beta_{1} \ln ($ Discount Rate $t)+\beta_{2} \ln \left(G P_{t}\right)+\varepsilon_{t}$

$\ln \left(\right.$ Credit Individual $\left.s_{t}\right)=\lambda+\beta_{1} \ln \left(\right.$ Discount Rate $\left.t_{t}\right)+\beta_{2} \ln \left(G P_{t}\right)+\varepsilon_{t}$

$\ln \left(\right.$ Credit Construction $\left._{t}\right)=\lambda+\beta_{1} \ln \left(\right.$ Discount Rate $\left._{t}\right)+\beta_{2} \ln \left(G_{D P}\right)+\varepsilon_{t}$

where, $\varepsilon$ is the error term, and $t$ is the time period that covers the years $1992-2019$. All variables are in real terms and in natural logarithm forms. The fact that the used data is annual (time series), the analysis follows few structured steps.

First, all of the variables are tested for their stationarity. This is done using the Augmented Dickey-Fuller unit root test. Second, each of the three models are tested for their optimal lag structures. This is done using the final prediction error (FPE), Akaike's information criterion (AIC), and Schwarz information criterion (SC), among others. Third, once we determine the optimum lags, we examine the three models for co-integration using both the Johansen-Masulius procedures (maximum eigenvalue / $\lambda_{\max }$ and the trace test $\left./ \lambda_{\text {trace }}\right)$. Fourth, based on the co-integrating tests, we perform either an unrestricted vector autoregressive (VAR) model (in the case of no co-integration) or a vector error-correction (VECM) model (if there is cointegration).

This VECM examines the three models in terms of their long-run and short-run relationship between their respective variables as follows.

$\Delta$ Total Credit $_{\mathrm{t}}=\alpha+\lambda e_{\mathrm{t}-1}+\sum_{i=1}^{n} b \mathrm{i} \Delta$ Discount Rate $_{\mathrm{t}-\mathrm{i}}+\sum_{i=1}^{n} b \mathrm{i} \Delta \mathrm{GDP}_{\mathrm{t}-\mathrm{i}}+\varepsilon_{\mathrm{t}}$

$\Delta$ Credit to Individuals $\mathrm{s}_{\mathrm{t}}=\alpha+\lambda e_{\mathrm{t}-1}+\sum_{i=1}^{n} b \mathrm{i} \Delta$ Discount Rate $\mathrm{t}_{\mathrm{t}-\mathrm{i}}+\sum_{i=1}^{n} b \mathrm{i} \Delta \mathrm{GDP}_{\mathrm{t}-\mathrm{i}}+\varepsilon_{\mathrm{t}}$

$\Delta$ Credit to Construction Sector ${ }_{\mathrm{t}}=\alpha+\lambda e_{\mathrm{t}-1}+\sum_{i=1}^{n} b \mathrm{i} \Delta$ Discount Rate $_{\mathrm{t}-\mathrm{i}}+\sum_{i=1}^{n} b \mathrm{i} \Delta \mathrm{GDP}_{\mathrm{t}-\mathrm{i}}+\varepsilon_{\mathrm{t}}$

Based on the results of the VECM, if the error correction term $(\lambda)$ is negative and significant, this implies the existence of a long-run convergence between the variables. Finally, we test the models if they have serial correlation in their residuals (Breusch-Godfrey serial correlation LM test, and the stability of their residuals (CUSUM test).

\section{THE EMPIRICAL RESULTS}

Based on the econometric analyses, we can raise the following observations and comments.

First, the Augmented Dickey-Fuller results (Table 1) reveal that all of the variables are stationary in their respective firstdifference form.

Table 1: Augmented Dickey-Fuller Unit Root Test

\begin{tabular}{|l|c|c|c|c|c|c|}
\hline & None & Constant & Constant \& Trend & None & Constant & Constant \& Trend \\
\hline Credit to Private Sector & 8.107 & -1.174 & -2.033 & $-1.7081^{* *}$ & $-3.544^{*}$ & $-3.565^{* *}$ \\
\hline Credit to Construction & 2.715 & -0.369 & -1.577 & $-2.288^{*}$ & $-3.761^{*}$ & $-3.647^{*}$ \\
\hline Credit to Individuals & 2.974 & -0.966 & -2.133 & $-3.722^{*}$ & $-8.244^{*}$ & $-7.418^{*}$ \\
\hline GDP & 3.671 & -0.4971 & -2.456 & $-3.388^{*}$ & $-3.028^{* *}$ & $-4.976^{*}$ \\
\hline
\end{tabular}




\begin{tabular}{|l|c|c|c|c|c|c|}
\hline Repo Rate & -0.273 & -2.154 & -2.358 & $-3.980^{*}$ & $-3.417^{*}$ & $-3.313^{*}$ \\
\hline * and ${ }^{*}$ imply significance at the 99 and 95 percent levels respectively. \\
\hline
\end{tabular}

Second, for the three endogenous variables (total credit, re-discount rate, and GDP and credit to construction, re-discount rate, and GDP), the optimal lag length is 2 (Tables 2 and 3 respectively). For credit to individuals, re-discount rate, and GDP) the lag length is 1 (Table 4).

Table 2: VAR Lag Order Criteria

\begin{tabular}{|l|l|l|l|l|l|l|}
\hline \multicolumn{6}{|c|}{ VAR Lag Order Selection Criteria: Endogenous Variables: Total Credit, GDP, \& Re-Discount Rate } \\
\hline Lag & LogL & LR & FPE & AIC & SC & HQ \\
\hline 0 & 5.862 & NA & 0.0001 & -0.228 & -0.082 & -0.188 \\
\hline 1 & 98.592 & 155.786 & $1.98 \mathrm{e}-07$ & -6.927 & -6.342 & -6.765 \\
\hline 2 & 116.130 & $25.255^{*}$ & $1.04 \mathrm{e}-07^{*}$ & $-7.610^{*}$ & $-6.586^{*}$ & $-7.326^{*}$ \\
\hline 3 & 120.113 & 4.7797 & $1.71 \mathrm{e}-07$ & -7.209097 & -5.746 & -6.803 \\
\hline
\end{tabular}

Table 3: VAR Lag Order Criteria

\begin{tabular}{|l|l|l|l|l|l|l|}
\hline \multicolumn{6}{|c|}{ VAR Lag Order Selection Criteria: Endogenous Variables: Credit to Construction, GDP, Re-Discount Rate } \\
\hline Lag & LogL & LR & FPE & AIC & SC & HQ \\
\hline 0 & -2.997 & NA & 0.0003 & 0.479 & 0.626 & 0.520 \\
\hline 1 & 93.416 & 161.975 & $3.00 \mathrm{e}-07$ & -6.513 & $-5.928^{*}$ & -6.351 \\
\hline 2 & 105.665 & $17.638^{*}$ & $2.40 \mathrm{e}-07^{*}$ & $-6.773^{*}$ & -5.749 & $-6.489^{*}$ \\
\hline 3 & 110.719 & 6.065 & $3.63 \mathrm{e}-07$ & -6.457 & -4.994 & -6.051 \\
\hline
\end{tabular}

Table 4: VAR Lag Order Criteria

\begin{tabular}{|l|l|l|l|l|l|l|}
\hline \multicolumn{6}{|c|}{ VAR Lag Order Selection Criteria: Endogenous Variables: Credit to Individuals, GDP, \& Re-Discount Rate } \\
\hline Lag & LogL & LR & FPE & AIC & SC & HQ \\
\hline 0 & -18.142 & NA & 0.001 & 1.691 & 1.837 & 1.732 \\
\hline 1 & 64.498 & $138.837^{*}$ & $3.04 \mathrm{e}-06^{*}$ & $-4.199^{*}$ & $-3.614^{*}$ & $-4.037^{*}$ \\
\hline 2 & 71.901 & 10.659 & $3.58 \mathrm{e}-06$ & -4.072 & -3.048 & -3.788 \\
\hline 3 & 82.498 & 12.716 & $3.47 \mathrm{e}-06$ & -4.199 & -2.737 & -3.794 \\
\hline
\end{tabular}

Third, using the estimated lag-lengths, the trace statistic and maximum eigenvalue results indicate that there is at least one co-integrating relationship in each of the three models (Table 5).

Table 5: Johansen Multivariate Co-Integration Test

\begin{tabular}{|c|c|c|c|c|c|c|c|c|}
\hline $\begin{array}{l}\text { Hypothesized } \\
\text { No. of CE(s) }\end{array}$ & $\begin{array}{l}\text { Eigen } \\
\text { Value }\end{array}$ & $\begin{array}{c}\text { Trace } \\
\text { Statistic }\end{array}$ & $\begin{array}{c}5 \text { percent } \\
\text { CV }\end{array}$ & P-Value & $\begin{array}{l}\text { Eigen } \\
\text { Value }\end{array}$ & $\begin{array}{c}\text { Max- } \\
\text { Eigen } \\
\text { Statistic }\end{array}$ & $\begin{array}{c}5 \text { percent } \\
\text { CV }\end{array}$ & P-Value \\
\hline \multicolumn{9}{|c|}{ Total Credit, GDP, \& Re-Discount Rate } \\
\hline None * & 0.516 & 29.926 & 29.797 & 0.048 & 0.5168 & 18.185 & 21.131 & 0.023 \\
\hline At most 1 & 0.337 & 11.740 & 15.495 & 0.169 & 0.3379 & 10.309 & 14.264 & 0.192 \\
\hline At most 2 & 0.055 & 1.431 & 3.841 & 0.232 & 0.055 & 1.431 & 3.841 & 0.231 \\
\hline \multicolumn{9}{|c|}{ Credit to Construction, GDP, \& Re-Discount Rate } \\
\hline None * & 0.630 & 38.271 & 29.797 & 0.004 & 0.631 & 24.902 & 21.131 & 0.014 \\
\hline At most 1 & 0.346 & 13.369 & 15.495 & 0.102 & 0.346 & 10.632 & 14.264 & 0.173 \\
\hline At most 2 & 0.104 & 2.7377 & 3.841 & 0.098 & 0.104 & 2.737 & 3.841 & 0.098 \\
\hline \multicolumn{9}{|c|}{ Credit to Individuals, GDP, \& Re-Discount Rate } \\
\hline None * & 0.797 & 51.458 & 29.797 & 0.000 & 0.797 & 41.485 & 21.131 & 0.000 \\
\hline At most 1 & 0.279 & 9.973 & 15.494 & 0.283 & 0.279 & 8.495 & 14.264 & 0.330 \\
\hline At most 2 & 0.055 & 1.477 & 3.841 & 0.224 & 0.055 & 1.477 & 3.841 & 0.224 \\
\hline
\end{tabular}

Fourth, based on the co-integration results, we estimate the vector error correction model for each of the three models. The results of this analysis are reported in Tables 6 and 7. 
The error correction term of the relationship between total credit and GDP and the re-discount rate is positive and significant $(+0.378)$. This implies that there is no long run equilibrium relationship between the total credit and GDP and the re-discount rate. The error correction term of the relationship between credit to construction and GDP and the re-discount rate is negative and significant $(-0.101)$. This implies that there is a long run equilibrium relationship between the credit to construction and GDP and the re-discount rate. The error correction term of the relationship between credit to individuals and GDP and the re-discount rate is negative and significant $(-0.421)$. This implies that there is a long run equilibrium relationship between the credit to individuals and GDP and the re-discount rate.

Table 6: Results of the Vector Error Correction Models (VECM)

\begin{tabular}{|c|c|c|c|}
\hline Variables & $\Delta \ln ($ Total Credit) & Variables & $\Delta \ln ($ Credit to Construction) \\
\hline $\mathrm{ECT}(-1)$ & $+0.378^{*}$ & $\mathrm{ECT}(-1)$ & $-0.101^{*}$ \\
\hline $\mathrm{D}$ (Total Credit)-1 & -0.216 & $\mathrm{D}$ (Construction)-1 & -0.245 \\
\hline $\mathrm{D}$ (Total Credit)-2 & -0.217 & $\mathrm{D}$ (Construction)-2 & -0.068 \\
\hline $\mathrm{D}(\mathrm{GDP})-1$ & +0.297 & $\mathrm{D}(\mathrm{GDP})-1$ & $1.089^{*}$ \\
\hline $\mathrm{D}(\mathrm{GDP})-2$ & +0.049 & $D(G D P)-2$ & 0.477 \\
\hline D(Repo)-1 & $+0.170^{*}$ & $\mathrm{D}($ Repo)-1 & $0.218^{*}$ \\
\hline $\mathrm{D}($ Repo)-2 & -0.023 & $\mathrm{D}($ Repo)-2 & $0.186^{*}$ \\
\hline C & $0.103^{*}$ & C & 0.001 \\
\hline
\end{tabular}

Table 7: Results of the Vector Error Correction Models (VECM)

\begin{tabular}{|l|c|}
\hline Variables & \multicolumn{1}{|c|}{$\boldsymbol{l n}$ (Credit to Individuals) } \\
\hline ECT(-1) & $-0.421^{*}$ \\
\hline D(Individuals)-1 & -0.123 \\
\hline D(GDP)-1 & $0.781^{*}$ \\
\hline D(Repo)-1 & $0.552^{*}$ \\
\hline C & 0.087 \\
\hline * Significant at the 99 percent level. \\
\hline
\end{tabular}

Fifth, as far as the long-run relationship is concerned, the impact of the change in GDP on credit to the construction sector is significant and equal to +0.795 and the impact of the change in the re-discount rate is equal -2.318 . In addition, the impact of the change in GDP on credit to individuals is significant and equal to +0.544 , while the impact of the change in the rediscount rate on credit to individuals is significant and equal to -0.907 .

Sixth, based on the reported values in Tables 8 and 9, we can conclude that there are no serial correlation problems in the models that regress GDP and the re-discount rate on credit to the construction sector, and on the credit to individuals. Similarly, both of these models are structurally or dynamically stable, and this can be seen from the CUSUM test results reported in Figures 4 and 5.

Table 8: Breusch-Godfrey Serial Correlation LM Test

\begin{tabular}{|l|l|l|l|}
\hline \multicolumn{4}{|c|}{ Credit to Construction, GDP, \& Repo } \\
\hline F-statistic & 0.548964 & Prob. F(1,20) & 0.5887 \\
\hline Obs*R-squared & 1.705077 & Prob. Chi-Square(1) & 0.4263 \\
\hline
\end{tabular}

Table 9: Breusch-Godfrey Serial Correlation LM Test

\begin{tabular}{|l|l|l|l|}
\hline \multicolumn{4}{|c|}{ Credit to Individuals GDP, \& Repo } \\
\hline F-statistic & 1.051792 & Prob. F(1,20) & 0.0978 \\
\hline Obs*R-squared & 1.379990 & Prob. Chi-Square(1) & 0.0964 \\
\hline
\end{tabular}


Figure 4: Credit to Construction, GDP, and Re-Discount Rate

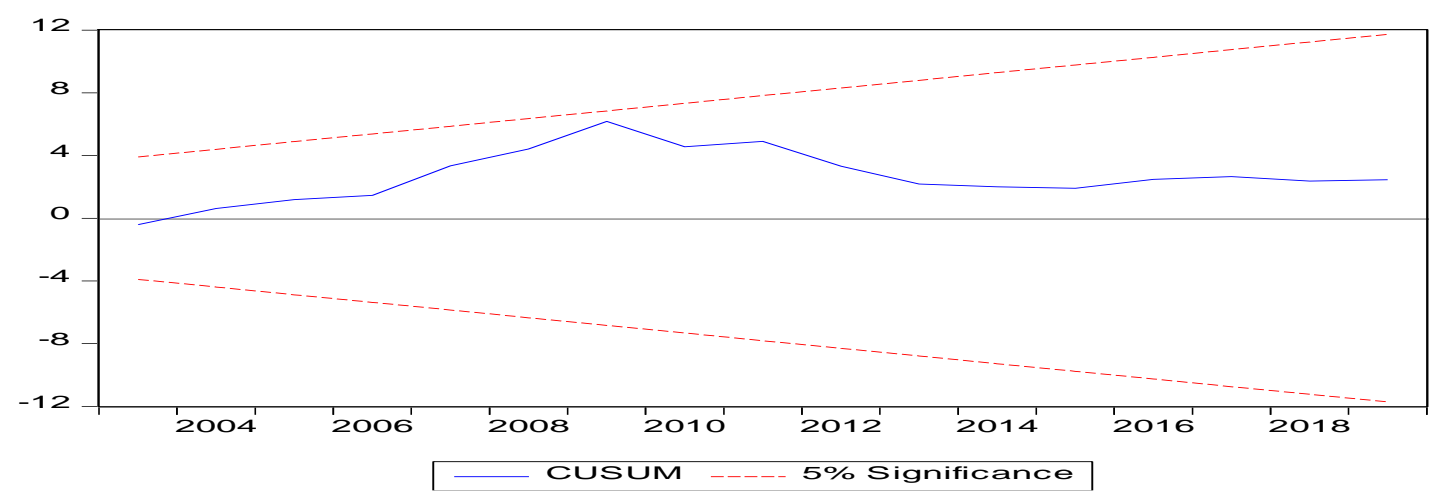

Figure 5: Credit to Individuals, GDP, \& Re-Discount Rate

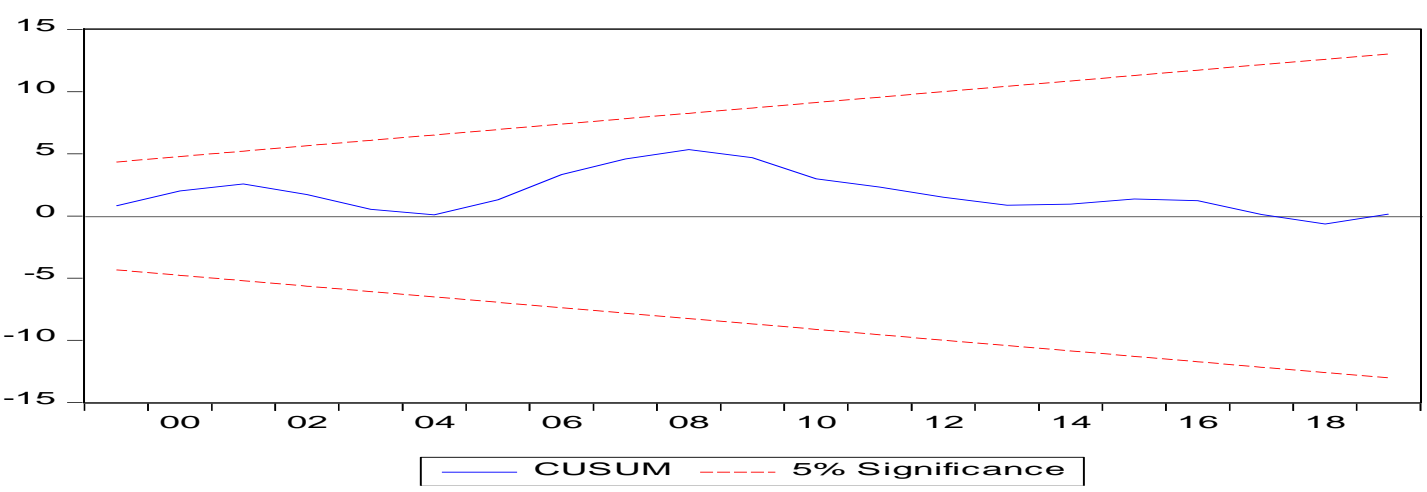

\section{A SUMMARY AND CONCLUSIONS}

The fact that monetary policy has the potential to impact the performance of the real economy, the monetary policy transmission mechanism has led to the development of a myriad of theoretical models, and a huge number of empirical papers.

As argued in the introduction, the importance of this paper rests on the argument that within the economic context of the implications of COVID-19 on the Jordanian economy, it has become even more important to understand the transmission mechanism of monetary policy.

Based on the period 1992-2019, the results show that monetary policy is not effective in its overall lending channel. Increases in interest rates do not lead to a reduction in total bank credit to the private sector, and vice versa. However, the results also reveal that that there is a stable long run relationship between bank credit to individuals and to the construction sector and monetary policy. Indeed, the long-run impact of interest rates on either credit to individuals or to the construction sector is negative.

To increase the effectiveness of the transmission mechanism of monetary policy in Jordan, relevant stakeholders would be well-advised to consider the establishment of a government (and corporate) securities market. Indeed, the absence if such a market weakens the transmission of changes in the short term policy rate to other points on the yield curve (Moreno, 2008). In addition, stakeholders should look into the impact of the lending behavior of licensed banks in Jordan in terms of their lending to the finance the budget deficits. Indeed, public sector borrowing from banks reduces the extent to which changes in the re-discount rate rapidly affect bank credit.

\section{REFERENCES}

Abbas, Z., Iftikhar, S. and Alam, S. (2019). Does bank capital affect the monetary policy transmission mechanism? A case study of Emerging Market Economies (EMEs). International Journal of Financial Engineering 6:

Agenor, PR, Aynaoui, KE, (2010). Excess Liquidity, Bank Pricing Rule, and Monetary Policy. Journal of Banking and Finance, 34, $923-933$.

Al-Jarrah, I., Abdulqader, K., Zeitun, R. and Ziadat, K. (2016). Examining the monetary policy transmission in Jordan: The bank lending channel. Dirasat, Administrative Sciences, 43, 249-262. 
Barajas, A., Chami, R., Ebeke, C. and Oeking, A. (2018). What's different about monetary policy transmission in remittance-dependent countries. Journal of Development Economics, 134, 272-288.

Bernanke, B. and Blinder, A. (1988). Credit, money and aggregate demand. American Economic Review, 78, $435-439$.

Bernanke, B. and Blinder, A. (1992). The federal funds rate and the channels of monetary transmission. The American Economic Review, 82, 901-921.

Bernanke, B. and Gertler, M. (1995). Inside the black box: the credit channel of monetary policy transmission. The Journal of Economic Perspectives 9, 27-48.

Brandao-Marques, L., Gelos, G., Harjes, T., Sahay, R. and Xue, Y. (2020). Monetary policy transmission in emerging markets and developing economies. IMF Working Paper No. 20/35.

Brayton, F. and Mauskopf, E. (1985). The federal reserve board MPS quarterly econometric model of the US economy. Economic Modelling, 2, 170-292.

Can, U., Bocuoglu, M. and Can, Z. (2020). How does the monetary transmission mechanism work? Evidence from Turkey. Borsa Istanbul Review, 20, 375-382.

Cecchetti, S. (1999). Legal structure, financial structure and the monetary policy transmission mechanism. NBER Working Paper No. 7151.

Christiano, L., Eichenbaum, M. and Evans, C. (1998). Monetary policy shocks: What have we learned and to what end? National Bureau of Economic Research Working Paper No. 6400.

Cushman, D. and Zha, T. (1995). Identifying monetary policy in a small open economy under flexible exchange rates. Federal Reserve Bank of Atlanta, Working Paper No. 95-7.

Dang., V. and Dang, V. (2021). Bank diversification and the effectiveness of monetary policy transmission: Evidence from the bank lending channel in Vietnam, Cogent Economics and Finance, 9, 1-20.

Kashyap, A. and Stein, J. (1995). The impact of monetary policy on bank balance sheets. Carnegie-Rochester Conference Series on Public Policy, 42, 151-195.

Leeper, E., Sims, C. and Zha, (1996). What does monetary policy do? Brookings Papers on Economic Activity, 2, 1-78.

Mishi, S. and Tsegaye, A (2020). Monetary policy transmission mechanism in South Africa: The bank lending channel and it's alternative. Academy of Accounting and Financial Studies Journal, 24, 1-18.

Mishkin, F. (1995). Symposium on the monetary transmission mechanism. Journal of Economic Perspectives, 9, 3-10.

Monticelli, C. and Tristani, O. (1999). What does the single monetary policy do? A SVAR benchmark for the European Central Bank. European Central Bank Working Paper No.2.

Moreno, R, 2008. Monetary Policy Transmission and Long Term Interest Rate in Emerging Markets. In Transmission Mechanism for Monetary Policy in Emerging Market Economies. No. 35, BIS.

Mukhtar, T. and Younas, M. (2019). Monetary policy transmission mechanism of Pakistan: Evidence from bank lending and asset channels. Asian Journal of Economic Modelling, 7, 121-139.

Nguyen, T., Papyrakisa, E. and Van Bergeijk, P. (2019). Assessing the price and output effects of monetary policy in Vietnam: evidence from a VAR analysis. Applied Economics, 51, 4800-4819.

Peersman, G. and Smets, F. (2001). The monetary transmission mechanism in the Euro area: More evidence from VAR analysis. European Central Bank Working Paper No.91.

Poddar, T., Sab, R. and Khachatryan, H. (2006). The monetary transmission mechanism in Jordan. IMF Working Paper No. 06/48.

Rachid. O. (2018). Monetary policy transmission mechanism in a small open economy under fixed exchange rate: An SVAR approach for Morocco. International Journal of Business and Economic Sciences Applied Research, 11, 42-51.

Sims, C. (1992). Interpreting the macroeconomic time series data. European Economic Review, 36, 975-1011. 